PF 2020 (75/1): 283-292

https://doi.org/10.32798/pf.661

\author{
KRYSTYNA KLESZCZOWA \\ professor emeritus \\ Uniwersytet Śląski w Katowicach \\ e-mail: krystyna.kleszcz@us.edu.pl \\ ORCID 0000-0003-4872-5484
}

\title{
WALENCJA ODCZASOWNIKOWYCH NAZW WYKONAWCÓW CZYNNOŚCI
}

\section{THE VALENCY OF DEVERBAL NOMINA AGENTIS}

\begin{abstract}
The collocability of deverbal words manifests their status within the category of nomina agentis. A derived word may be an element of a specific description, indicating the referent in a direct manner (odkrywca Ameryki 'the one who discovered America' = Christopher Columbus; twórca Facebooka 'the creator of Facebook' = Mark Elliot Zuckerberg). A separate class is constituted by the names that specify the final value of the verb, thus acquiring a sense of singularity: odkrywca penicyliny 'the one who discovered penicillin' (Alexander Fleming), twórca Symfonii patetycznej 'the author of Symphony No. 6 in B minor' (Pyotr Tschaikovski). However, the majority of names point to the items determined by a specific context or consituation. This obviously does not mean that such an item should stand by an agentive name, cf. Jeżeli komuś sprzedaje obraz, to nabywca [obrazu] otrzymuje gwarancje trwałości mojego wyrobu. The names of professions usually block the indication of the object of the activity, if only it is inscribed into the meaning of the derived word (we do not say ${ }^{\star}$ piekarz chleba ' the baker of bread', etc.). However, surface objects can also be blocked - for different reasons - when accompanying the names of people who demonstrate particular proclivities or skills (rozrabiacz, majsterkowicz, szperacz). Since names like these refer to generalised objects, the indication of one element of the set yields an unacceptable expression, cf. ${ }^{\star}$ majsterkowicz samochodzików, ${ }^{\star}$ żarłok kotletów, ${ }^{\star}$ pijak piwa.

The form of the object of the activity, appearing next to the derived word, is usually constant - these are nouns in the genitive case, even if they had a different form in the past (dative and instrumental cases).
\end{abstract}

KEYWORDS: word formation, obligatory collocability, blocking of collocability 
SŁOWA KLUCZOWE: słowotwórstwo, łączliwość obligatoryjna, blokady w łączliwości

Stosowanie narzędzi składniowych w analizach słowotwórczych ma już długą tradycję w lingwistyce slawistycznej. Derywat traktowany jest jako efekt uniwerbizacji podstawowej struktury predykatowo-argumentowej (PSPA), wartość słowoformy określa się na podstawie parafrazy słowotwórczej, która zazwyczaj ma postać zdania ${ }^{1}$. Powiedzieć wręcz można, że składnia zawsze „wpisana” była w słowotwórstwo (Grzegorczykowa, Puzynina 1984). W niniejszym artykule problemy składniowe będą inaczej potraktowane. Interesować nas będą cechy składniowe rzeczowników powstałych na bazie czasowników. Pytania brzmią: jakie wymagania składniowe ma derywat?; które elementy struktury PSPA bazowego czasownika wiązane są przez powstały od niej rzeczownik?; które są obligatoryjne, które fakultatywne?; które są zablokowane? Analizy ograniczam do osobowych nazw wykonawców czynności ${ }^{2}$. Te wydają się najlepszym materiałem do zapowiedzianych rozważań, a to $\mathrm{z}$ dwóch powodów: 1/ kategoria nazw wykonawców czynności jest najsilniejszą klasą odczasownikowych derywatów, klasą naznaczoną bardzo wyrazistymi formantami już od czasów prasłowiańskich (Wojtyła-Świerzowska 1974); 2/ w każdym opisie tej klasy podkreśla się jej wewnętrzne zróżnicowanie semantyczne - jedne derywaty wskazują na zawód (goniec), inne na skłonności (podrywacz), umiejętności (wspinacz), są też takie, które zbliżają się do nazw własnych (Stwórca, Odkupiciel) itd.

Problem przejmowania cech składniowych przez derywat odczasownikowy postrzegać można w kilku aspektach, będą one decydowały o kompozycji niniejszego tekstu. Można zapytać, które argumenty podstawowej struktury predykatowo-argumentowej (PSPA) wiązane są przez agentywny derywat (fragment 1.). Jak pokażą analizy, niektóre uzupełnienia derywatu są obligatoryjne, por. zdobywca medalu, niektóre fakultatywne (sprzedawca (samochodu)), niektóre zaś - zablokowane (piekarz * chleba). O przyczynach takiego funkcjonowania odczasownikowych nazw wykonawców czynności mowa będzie we fragmencie 2 .

1 Piszę zazwyczaj, bo o uniwerbizacji mówi się również w przypadku powstawania jednego wyrazu z grupy nominalnej, por. zupa grochowa > grochówka, szkoła podstawowa > podstawówka. Tu bazą jest wyrażenie przymiotnikowo-rzeczownikowe. Wobec takich uniwerbizacji dobrze byłoby posługiwać się nazwą: derywaty predykatywne, tzn. powstałe na bazie zdania (Kleszczowa 2018).

2 Szerzej traktuje nazwy wykonawców czynności Teresa Dobrzyńska, w ich obręb włącza nazwy środków czynności, nazwy maszyn, zwierząt, np. utleniacz, rysik, barwiarka, leniak (Dobrzyńska 1975). Przyjmuję, że wykonawcą czynności jest agens, „istota działająca, a więc będzie to zarówno ktoś [= istota żywa], kto coś robi, jak i ktoś [= istota ludzka], kto coś robi i wie, że to coś robi. W obu przypadkach stosowane jest pytanie Co robi X?” (Zaron 2012, s. 93). 
Postać fleksyjna dziedziczonego argumentu jest na ogół jednolita (dopełniacz), odstępstwa są nieliczne; traktować o nich będzie fragment 3.

I już w tym miejscu pragnę podkreślić, że interesują mnie typowe układy walencyjne analizowanych słowoform. Warto w tym miejscu przytoczyć słowa Andrzeja Bogusławskiego, pomieszczone w opisie orzeczeń peryfrastycznych:

Nie oznacza to, iżby wśród zdaniowych kształtów fonologicznych nie można było znaleźć okazów nie mieszczących się w tej charakterystyce. Takie okazy występują w poezji, zwłaszcza eksperymentalnej, w żartach słownych, w zdaniach z pewnymi neologizmami tworzonymi ad hoc itd. Chodzi jednak o to, że zjawiska tego rodzaju stanowią, ilościowo rzecz biorąc, margines całokształtu ludzki „zachowań mownych” i, co ważniejsze, funkcjonują właśnie jako sposoby odejścia od rutyny powszednio -językowej, funkcjonują na tle rutyny, w zderzeniu z nią, a więc są od niej logicznie zależne. (Bogusławski 1978, s. 18)

Kończąc wprowadzenie do analiz, chciałabym dodać, że biorę pod uwagę jedynie nazwy osobowych sprawców czynności, na boku stawiam nazwy typu posłaniec, zesłaniec, opętaniec - derywaty te powstały na bazie imiesłowów biernych, mnie interesują derywaty strukturalizujące argument agentywny PSPA.

1. Nazwy wykonawców czynności (Ag) z reguły wiążą dwa argumenty PSPA - obiekt (Pt) bądź rezultat czynności (Res). Są to zazwyczaj argumenty obligatoryjne w zdaniu realizującym czasownikowe PSPA, por. Jan wielbi (coś = Pt); Jan tworzy (coś = Res), nic zatem dziwnego, że te wymagania składniowe dotyczą również derywatów powstałych na takiej bazie, zatem: wielbiciel Anny/ muzyki Chopina; twórca obrazu/ nowego kierunku w sztuce. Już podane tu przykłady pokazują, że rolę Pt i Res należy traktować szeroko, chodzi nie tylko o konkretny obiekt, ale też o byty abstrakcyjne, por. twórca teorii względności, krzewiciel oświaty, organizator konferencji. Gdyby odnieść powyższe do tradycyjnej składni, można by tu mówić o różnego typu przydawkach rzeczownikowych - właściwościowych (kompozytor światowej sławy), dopełniających (zarządca gmachu) (Klemensiewicz 1969, s. 56-65).

Jeśli chodzi o środek czynności, zatem instrument, substancję i materiał (Grochowski 1975), to w zgromadzonym materiale nie spotkałam jego strukturalizacji przy nazwie wykonawcy czynności. Dziwnie brzmiałoby wyrażenie: pisarz powieści długopisem ( $\leftarrow x$ pisał tę powieść długopisem). Powiedzieć wręcz można, że omawiane tu słowoformy mają zdolność wiązania jednego tylko argumentu - Pt albo Res. Jedynie argumenty Loc i Temp mogą pojawić się obok nich, ale wiadomo, że każda czynność odbywa się w określonym czasie i przestrzeni. Nie dziwią więc połączenia, z reguły wyrażenia przyimkowe, typu: odnowiciel fresku $w$ katedrze $e^{3}$. Wyrażeniem strukturalizującym Temp może być $w$ tym roku wobec

3 Choć zdanie nie jest jednoznaczne - wyrażenie $w$ katedrze może być traktowane jako Loc ( $x$ odnawiał fresk $w$ katedrze), ale też jako element wyrażenia fresk $w$ katedrze (= katedralny fresk). 
organizator konferencji ( $w$ tym roku). Informację o czasie i miejscu niesie zazwyczaj całe zdanie, w którym funkcjonuje nazwa agentywna.

Osobną kwestię stanowią argumenty zdarzeniowe implikowane przez niektóre PSPA, te są nieraz niezbywalnym elementem czasownikowego wyrażenia predykatywnego. Jeżeli ktoś demonstruje, to przeciwko czemuś; demonstrant również wiąże argument $\mathrm{w}$ tej formie. Jeżeli Jan pomaga synowi $w$ zarzadzaniu przedsiębiorstwem, to Jan jest pomocnikiem syna w zarządzaniu. Grać też wiąże jakieś zdarzenie, zatem i dla gracza argument zdarzeniowy jest obligatoryjny (gracz na giełdzie). Strukturalizacja argumentu zdarzeniowego przy rzeczowniku jest różna: demonstrant przeciwko czemuś, pomocnik w czymś, gracz na zawodach, gracz w piłkę nożną.

2. Dziedziczenie obligatoryjnego argumentu czasownikowej PSPA ma różną postać, co zazwyczaj wiąże się z semantyką utworzonego derywatu agentywnego, także $\mathrm{z}$ charakterem argumentu PSPA.

2.1. Zacznijmy od derywatów powstałych na bazie deskrypcji określonych, w których rzeczowniki agentywne wiążą argumenty z kwantyfikatorem ogólnym: Stwórca (wszystkiego na świecie), Stworzyciel (świata), Odkupiciel (wszystkich lu$d z i$ ). Argumenty implikowane przez bazy stworzyć, odkupić nie muszą się pojawiać na powierzchni, bowiem powstałe na takiej bazie rzeczowniki funkcjonują jako nazwy własne, są synonimiczne wobec Bóg, dlatego zapisywane są tu dużymi literami.

Bliskie powyższym są derywaty będące deskrypcjami określonymi z nazwami własnymi, deskrypcje te również wskazują na konkretne osoby, por. odkrywca Ameryki (Krzysztof Kolumb), twórca Facebooka (Mark Elliot Zuckerberg), zdobywca bieguna południowego (Roald Engelbregt Gravning Amundsen). Już ostatni z podanych tu przykładów mieści uzupełnienie stojące na granicy między nazwami własnymi a pospolitymi. Bo nazwy pospolite często są elementami deskrypcji, $\mathrm{z}$ definicji nieokreślonych, ale $\mathrm{w}$ sposób jednoznaczny wskazujących na konkretną osobę, por. wynalazca piorunochronu (Beniamin Franklin), odkrywca penicyliny (Alexander Fleming), twórca Symfonii Patetycznej (Piotr Czajkowski). W podawanych tu przykładach mamy nazwy agentywne powstałe na bazie czasowników niedokonanych (tworzyć, zdobywać, odkrywać), choć w parafrazie słowotwórczej pojawiaja się czasowniki dokonane, por. 'ktoś, kto odkrył Amerykę,, 'ktoś, kto stworzył Symfonię Patetyczną'. Jadwiga Puzynina dla takich przykładów upatruje zjawiska neutralizacji aspektu (Puzynina 1969, s. 87-89). Wydaje się jednak, że lepiej interpretować te przykłady fazowością czynności wyrażanej czasownikiem niedokonanym - dokonaność w parafrazie sygnalizuje fazę finalną zdarzenia (tworzyć i w efekcie stworzyć, odkrywać i od$k r y c ́)$, fazę finalną i jednocześnie jednokrotność zdarzenia - odkryć, wynaleźć, stworzyć wskazane obiekty można tylko raz (Kleszczowa 2020). 
W tym miejscu warto przypomnieć artykuł Marii Honowskiej o nominatywnej funkcji słowotwórstwa. Derywaty mutacyjne dzieli Maria Honowska na okazy i typy. Okazy to derywaty wskazujące desygnaty bez zastosowania środków referencyjnych, wtedy „nominację można by usytuować na pograniczu między apelatywami a nazwami własnymi: Nomen stanowiące produkt nominacji nie wymaga zabiegów wyznaczoności, równocześnie jednak nie jest semantycznie puste, charakteryzuje Okaz, a nie zbiór w sposób jednak okazjonalny, czytelny dla małej społeczności." (Honowska 1994, s. 90). Jak pokazały dotychczasowe rozważania, w odczasownikowych nazwach osób wskazać można trzy typy budowania okazów. Obok derywatu mutacyjnego może pojawić się argument o kwantyfikacji ogólnej (Stwórca świata), może pojawić się nazwa własna (odkrywca Ameryki), może też pojawić się nazwa wskazująca na finalny efekt czasownika bazowego (wynalazca piorunochronu).

2.2. Prócz derywatów opartych o deskrypcje określone i quasi-określone, dających w efekcie odesłanie do konkretnych osób, mamy cały szereg nazw wykonawców czynności odnoszących się do osób, których tożsamość uwarunkowana jest większym kontekstem.

Nie można bez wskazania obiektu czynności powiedzieć adorator, wielbiciel, nabywca. Musimy wyspecyfikować obiekty (Pt albo Res): adorator Marii, wielbiciel muzyki Chopina, nabywca samochodu, producent komputerów itd. Te nieokreślone deskrypcje wskazują na konkretną osobę, ale dla jej wyznaczenia niezbędny jest kontekst bądź konsytuacja. Bo adorować można różne kobiety, wielbić można również muzykę Mozarta czy Haydna, a nabywamy różne rzeczy, nie tylko samochód. Pokazane tu „obiekty” nie muszę pojawiać się obok nazwy wykonawcy czynności, wystarczy, że znajdują się gdzieś w kontekście:

Jeżeli komuś sprzedaję obraz, to nabywca [obrazu] otrzymuje gwarancję trwałości mojego wyrobu. NKJP;

Mogło to zapowiadać radykalne zmiany. Tym bardziej że w spokojnym i cichym życiu mojej córki pojawił się pierwszy adorator [córki], Marcin, będący jej partnerem do walca. NKJP;

Przedstawiciel Philipsa Stanisław Kozłowski zapytany o wysoką cenę żarówek powiedział, że wytwórca [żarówek] nie ma wpływu na cenę produktu, ale istnieją sklepy patronackie, gdzie można je kupić taniej. NKJP;

Zaciągnął się, jak mógł głęboko, odorem jej ubioru. Jego poprzedni użytkownik [ubioru] nie słyszał chyba nigdy o takich wynalazkach jak łaźnie czy mydło (...). NKJP.

Zdarza się, że Pt (bądź Res) zostają wchłonięte przez nazwę czynności, czego efektem jest blokada obiektu powiązanego z nazwą wykonawcy czynności. Dziś już nie powiemy piekarz ${ }^{*}$ chleba, ale jeszcze w XVI spotkać można takie połączenia: 
Też ustawiamy: iż Mieszczanie Bocheńscy albo kupcy soli mają mieć zupełną moc pospolitą sól wozić do składu Krakowskiego/ dla Piekarzów chleba SarnStat 373 (SXVI);

Pistor dilucidarius, łakotnych rzeczy piekarz, kołacznik. Mącz 300c (SXVI).

Nie mówimy lekarz ${ }^{*} l u d z i$, bo argument ludzie wpisany jest w derywat, to samo odnosi się do kreślarz ${ }^{*}$ rysunków technicznych czy drukarz ${ }^{\star} k s i a ̨ z ̇ e k$; niezręczne jest wyrażenie śpiewak arii, lepiej dookreślić nazwę przymiotnikiem: śpiewak operowy, ujeżḋacz to 'ten, kto ujeżdża konie', obiekt czynności wpisany jest w derywat i nie mówimy ${ }^{*} u j e \dot{z} d \dot{z} a c z$ koni. W nazwach profesji rzadko spotyka się specyfikowanie obiektu czynności. Tak było i w przeszłości, wyjątkowe są przykłady typu:

Ci najmali tymi pieniędzmi ... kowale żelaza i miedzi (fabros... ferri et aeris) BZ II Par24 (SStp);

Plumarius - Tkacz kobierców, kobierzecznik. Calep 814b (SXVI).

I nic dziwnego, że nazwy zawodów często leksykalizują się, por. krawiec ( $\leftarrow$ psł. ${ }^{\star} k r a v b c b$, derywat od psł. $\left.{ }^{\star} k r a v a t i\right) ;$ szewc ( $\leftarrow{ }^{\star}$ sbvbcb od psł. ${ }^{*}$ siti); kowal $\left(\leftarrow{ }^{\star} k\right.$ ovals od psł. $\left.{ }^{\star} k o v a t i,{ }^{\star} k o v Q{ }^{*} k u j Q\right)$. W klasie nazw zawodów nieliczne derywaty wymagają dookreślenia, dzieje się tak wtedy, gdy nazwa agentywna może dotyczyć różnych obiektów, por. hodowca drobiu, hodowca owiec, hodowca alpak; poławiacz (pereł, homarów, ostryg).

Na drodze do ograniczenia zakresu jest obrońca (oskarżonego). Piszę „na drodze", bo wyrazu obrońca można użyć w innym znaczeniu niż 'mecenas'. Wtedy derywat musi być dookreślony, por. obrońca uciśnionych, obrońca pokoju. Takich nazw, funkcjonujących bez dookreślenia i jednocześnie z koniecznym dodaniem przydawki rzeczownikowej, jest sporo. Chodzi tu głównie o nazwy zawodów ukute na bazie czasowników, które mogą również fundować okazjonalne nazwy wykonawców czynności. I np. obok sprzedawcy 'ekspedienta' można powiedzieć sprzedawca samochodu/domu; obok kupiec 'osoba trudniąca się handlem' mamy w zasobie polszczyzny kupiec w znaczeniu 'nabywca'.

W tym miejscu warto zwrócić uwagę na nazwy typu lekarz, wiadomo, że to 'ktoś kto leczy ludzi', ale można również powiedzieć lekarz Marii - ze zbioru ludzi specyfikujemy Marię. Możemy użyć nazwy nauczyciel bez uzupełnienia, wiadomo, że to ktoś, kto naucza dzieci albo młodzież, ale też połączenie nauczyciel Jacka - wyspecyfikowany jest jeden obiekt zbioru. Można również dookreślić wskazane nazwy zawodów: lekarz rodzinny, nauczyciel dzieci upośledzonych. Widzimy, że nadrzędna zasada w blokowaniu argumentu może być z różnych powodów uchylana.

Do omówienia zostały nazwy, które nazywają osoby o różnych skłonnościach bądź umiejętnościach, por. rozrabiacz, swawolnik, szperacz, majsterkowicz, żarłok, pijak. Nazwy te nie przyjmują obok siebie dookreślenia, mimo że podstawy słowotwórcze niektórych wiążą obiekt w sposób obligatoryjny. I np. obok 
czasownika podszczypywać pojawia się Pt: Bywalcy podszczypuja w knajpach kelnerki [...]. (WSJP), ale w utworzonym od niego derywacie agentywnym obiekt jest zablokowany: * podszczypywacz Ani/ kelnerek. Podobnie wygląda sprawa z parą podrywać - podrywacz; podrywać wiąże Pt, ale nie powiemy ${ }^{\star}$ podrywacz koleżanki z klasy. Kłamca to 'ktoś, kto kłamie, kto mówi bliźnim rzeczy nieprawdziwe', ale niepoprawne jest wyrażenie z wyspecyfikowaną osobą: ${ }^{\star} k ł a m c a ~ k o-$ legów, podobnie sprawa wygląda z rzeczownikiem oszust. Nie powiemy ${ }^{\star} \dot{z} a r ł o k$ kotletów, ${ }^{\star}$ pijak piwa. W pokazanych tu nazwach obiekt czynności musi mieć charakter ogólny, niemożliwe jest specyfikowanie jakiegoś elementów zbioru.

3. Już przytoczone wyżej przykłady pokazują, że wiązana przez nazwy wykonawców czynności przydawka rzeczownikowa ma postać dopełniacza: znalazca dokumentów, uczestnik konferencji, zawiadowca stacji.

Wiązane przez nazwę agentywną uzupełnienie w celowniku to rzadkie przypadki. Dziś wskazać można jedynie rzeczowniki przyjaciel i towarzysz, choć przez postawienie obok nich uzupełnienia celownikowego uzyskujemy walor archaiczny ${ }^{4}$. Waloru tego nie miały rzeczowniki przyjaciel i towarzysz w przeszłości, zwłaszcza że funkcjonowały obok innych użyć tego typu:

Słońce które jest wielki przyjaciel żywotowi człowieczemu/ gdy będzie promieni mdłych/ i gorącość jego mdła [powstawa morowe powietrze] FalZioł V 72 (SXVI)

Żona ma być mężowi żywota towarzyszem. Petr Ek. 70 (SL)

Jakom ja nie był pomocnikiem synowi swemu ... ku zabiciu Jana 1493 ZapWarsz nr 1754 (SStp)

Alem nie jest pochlebcą / sławie twej nijakiem. PaprPan A4v (SXVI);

Józefa onego ten Patryjarcha zostawił opiekunem synowi swemu Skarżyw 457 (SXVI); iż on [Bóg]zawżdy wiernym swym jest miłościwym opiekadlnikiem LubPs Z6v (SXVI); Aczkolwiek był wszem dobrym opatrzycielem/ a wżdy nie mógł być na swym stolcu spokojem BielKron 181 (SXVI);

Bo go karze [człowiek człowieka] nieprawdę jednemu/ a on sam wszytkim łgarzem. (...) RejZwierc 77v (SXVI);

Przeto czynił źle w widzeniu bożem jako i dom Achabow, bo byli oni jemu radźce po śmierci oćca jego BZ II Par 22 (SStp).

Dziś po rzeczownikach opiekun, pomocnik, radca, pochlebca dajemy rzeczownik w dopełniaczu. Powodem jest zapewne zmiana rekcji bazowych czasowników (Pisarkowa 1984, s. 96-97).

\footnotetext{
4 Rzeczownik przyjaciel powstał na bazie psł. * prijati, pochodny od niego staropolski czasownik przyjajać wiązał celownik: Ja ciebie proszę... przez twe wszystko dostojeństwo, przyjaj mi tego, abych ja... mogła przyjąć ciebie samego Naw 118 (SStp). Na temat losów rzeczownika towarzysz zob. Zaron 2010.
} 
Całkiem już marginalne jest pojawienie się przydawki rzeczownikowej w narzędniku. I tak manipulować funduje dwa synonimiczne rzeczowniki: manipulator oraz manipulant. W obu rzeczownikach obiekt manipulacji (Pt) strukturalizowany jest narzędnikiem

Wytrawny znawca ludzkich dusz i zręczny manipulator namiętnościami, mistrz

Wolfgang miał rację, kiedy mówił, że nikczemnika łatwo usidlić. NKJP

Inaczej ma się rzecz z rzeczownikiem handlarz. Wiąże on zarówno narzędnik, jak i dopełniacz; możemy powiedzieć handlarz starociami, bydłem, końmi, ale połączenia te są wymienne z: handlarz staroci, bydła, koni. Jednak wymienność $\mathrm{z}$ dopełniaczem nie jest regułą, bo skostniałe handlarz $\dot{z}$ ywym towarem utrzymuje starą formę narzędnikową: Jeżeli nawet jest to handlarz żywym towarem, to i tak cud, że uznał mnie za towar, czyż nie? Jakżeby mógł żyć bez oszukaństwa! NKJP.

Jak widać, dopełniacz przy nazwie wykonawcy czynności jest najczęstszy, co więcej - ruguje inne formy. Widać to jeszcze wyraźniej, gdy spojrzeć na przykłady z przeszłości języka, w których dookreślenie ma postać wyrażenia przyimkowego. Oto garść przykładów ze SXVI:

Dziwować się każdy może tak wielkiemu Greckiemu i Ruskiemu/ (...) uporowi: iż nas Katoliki zwać do tego czasu w pismach swoich Ruskich bluźniercami na ducha S. i heretykami nieprzestają SkarJedn 275;

Tak w Rzeczypospolitej jako w każdej sprawie/okaże się [Szafraniec] na jaśnią miłośnikiem prawie. RejZwierc 183;

Limenarcha. Graeca vox est, Latine portuum praefectus, Starosta albo porucznik nad porty morskiremi. Mącz 194a;

(...) nie chlubcie się. a nie bądźcie mataczmi przeciwko prawdzie Leop Iac 2/14;

Podoba się też nam zdanie WM, żebyśmy dworzany nasze litewskiego narodu obrócili do wojska, dla przywodziec i poruczeństwa nad ludźmi ListyZygm.Aug 1564/472.

\section{Zakończenie}

Powyższe analizy pokazały, które i w jakiej formie argumenty wymagane przez czasownikowe wyrażenie predykatywne dziedziczone są przez powstałe na ich bazie nazwy wykonawców czynności. W trakcie gromadzenia materiału punktem wyjścia nie były derywaty rzeczownikowe, a ich czasowniki bazowe. I właśnie ten sposób poszukiwań ujawnił nowy problem, nie poruszany w niniejszym tekście. Otóż są takie klasy czasowników, które nie tworzą nazw wykonawców. I np. nie tworzą nazw wykonawców czynności czasowniki wskazujące na ruch ciała: iść,

5 Niestety, nie udało mi się znaleźć odpowiedniego cytatu ani w NKJP, ani w WSJP. Łączliwość z narzędnikiem przypisuję derywatowi na podstawie własnej intuicji językowej. 
potknać się, mrugaćl mrugnać, machaćl machnąć (ręka), obracaćl obrócić się, schylaćl schylić się. Trudno wskazać sprawcę czynności od czasowników percepcyjnych: widzieć, patrzeć, slyszeć, słychać, stuchać, czuć, wachać, dotykać, smakować.

Wszystko, co się dzieje w percepcji, jest całkowicie zdeterminowane przez bodźce fizyczne i procesy fizjologiczne, a nie przez celowe usiłowania percypującego. Określiwszy percepcję jako stan, argumentowi odnoszącemu się do elementu związanego zmysłowo z owym stanem przypisujemy rolę semantyczną Doświadczający (Exp). (Grzesiak 1983, s. 15).

Pozornie przeczą temu derywaty widz oraz stuchacz. Jednak widz mieści w sobie nie stan (Janek widzi mysz), ale aktywnego odbiorcę jakiegoś widowiska. Stuchacz to nie osoba doznająca wrażeń słuchowych, ale aktywny uczestnik, por. stuchacz wy$k \nmid a d u^{6}$. Generalnie czasowniki stanowe nie tworzą nazw agentywnych, co nie dziwi, wszak nie może strukturalizować się coś, czego brak w PSPA. Jeżeli pojawi się taki derywat, mieści on treści, których nie było w czasowniku bazowym, por. ekspresywne rzeczowniki śpioch, smakosz. Jak widać, naruszenie ogólnej zasady zdradza dodatkowe wartości słowoformy.

\section{Bibliografia}

Bogusławski, A. (1978). Jednostki języka, a produkty językowe. Problem tzw. orzeczeń peryfrastycznych. W: M. Szymczak (red.), Z zagadnień wspótczesnego języka polskiego (17-30). Wrocław.

Dobrzyńska, T. (1975). Opozycja potencjalność - aktualność w polskich współczesnych nazwach wykonawców czynności, Poradnik Językowy, 289-295.

Grochowski, M. (1975). Środek czynności w strukturze zdania. Narzędzie, substancja, materiał. Wrocław.

Grzegorczykowa, R., Puzynina, J. (1984). Słowotwórstwo. W: Gramatyka współczesnego języka polskiego. Morfologia (307-407). R. Grzegorczykowa, R. Laskowski, H. Wróbel (red.). Warszawa.

Grzesiak, R. (1983). Semantyka i składnia czasowników percepcji zmysłowej. Katowice.

Honowska, M. (1994). Problem nominacji. Poradnik Językowy, 88-90.

Kleszczowa, K. (2018). Od uniwerbizacji do derywatów predykatywnych. W: ZBORNIK RADOVA Osamnaesta međunarodna naučna konferencija Komisije za tvorbu riječi

${ }_{6}$ W SStp odnotowany jest derywat patrzyciel (Patrzyciel contemplator 1425 PF V 33), w SXVI pojawia się jego synonim patrzacz (Spectator, Patrzacz/ przyglądacz. Mącz 405a). Jednak gdy spojrzymy na bazowe czasowniki patrzać i patrzyć, okaże się, że wskazane tu derywaty ukute zostały na innym znaczeniu niż 'mieć zdolność widzenia. Czasowniki te znaczyły 'obserwować,' 'pilnować, 'myśleć o czymś,' 'oglądać... 
Međunarodnog komiteta slavista Univerbacija/Univerbizacija u slavenskim jezicima Sarajevo, 4-7. aprila 2017. Urednica A. Šehović. Slavistički komitet. Sarajevo, 194-204;

Kleszczowa, K. (2020). Kategoria jednokrotności w polskich czasownikach, LingVaria (15), nr 2 (30), 79-88.

Pisarkowa, K. (1984). Historia składni języka polskiego. Wrocław.

Puzynina, J. (1969). Z metodologii badań nad derywatami odczasownikowymi, Biuletyn Polskiego Towarzystwa Językoznawczego XXVII, 83-92.

Wojtyła-Świerzowska, M. (1974). Prasłowiańskie nomen agentis. Wrocław.

Zaron, Z. (2010). Zmienne losy towarzysza. Wędrując po słownikach... Poradnik Językowy 1, 50-56.

Zaron, Z. (2012). Problemy składni funkcjonalnej. Zagadnienia ogólnoteoretyczne. Warszawa.

\title{
Słowniki
}

SL - Linde, S.B., Słownik języka polskiego, t. 1-6, Warszawa, 1807-1814;

SXVI - Słownik polszczyzny XVI wieku, red. M.R. Mayenowa, F. Pepłowski, K. Mrowcewicz, t. 1-35, Wrocław-Warszawa 1966-2011;

SStp - Słownik staropolski, t. 1-11, red. S. Urbańczyk, Wrocław-Kraków 1953-2002;

WSJP - Wielki słownik języka polskiego PAN, red. P. Żmigrodzki. Kraków 2007(https://www.wsjp.pl/)

NKJP - Narodowy Korpus Języka Polskiego (http://nkjp.pl)

\begin{abstract}
ABSTRAKT: Łączliwość odczasownikowych derywatów zdradza ich status w obrębie kategorii nazw wykonawców czynności. Derywat może być elementem deskrypcji określonej, ta w sposób bezpośredni wskazuje na desygnat (odkrywca Ameryki = Krzysztof Kolumb; twórca Facebooka = Mark Elliot Zuckerberg). Osobną klasę stanowią nazwy specyfikujące wartość finalną czasownika, uzyskując tym samym sens jednokrotności: odkrywca penicyli$n y$ (Alexander Fleming), twórca Symfonii Patetycznej (Piotr Czajkowski). Jednak większość nazw wiąże obiekt wyznaczony konkretnym kontekstem bądź konsytuacją, nie znaczy to oczywiście, że ten obiekt stoi przy nazwie agentywnej, por. Jeżeli komuś sprzedaję obraz, to nabywca [obrazu] otrzymuje gwarancje trwałości mojego wyrobu. Nazwy zawodów zazwyczaj blokują wskazanie obiektu czynności, jest on wpisany w znaczenie derywatu, nie mówimy * piekarz chleba. Choć z innych powodów, blokady w ujawnianiu obiektu dotyczą również nazw osób o określonych skłonnościach bądź umiejętnościach (rozrabiacz, majsterkowicz, szperacz). Nazwy te dotyczą ugólnionych obiektów, wskazanie jednego z elementów zbioru tworzy wyrażenie nieakceptowalne, por. *majsterkowicz samochodzików, *żarłok kotletów, ${ }^{*}$ pijak piwa. Forma obiektu czynności, który pojawia się obok derywatu, jest na ogół jednolita - to rzeczowniki w dopełniaczu, nawet wtedy, gdy w przeszłości miały inną postać (celowniki i narzędniki).
\end{abstract}

